\author{
ks. Arkadiusz Baron ${ }^{1}$ \\ 0000-0002-3255-4855 \\ Uniwersytet Papieski Jana Pawła II w Krakowie
}

\title{
Nauka o Duchu Świętym w Pasterzu Hermasa na tle problematyki pneumatologicznej. Studium wprowadzające
}

Świat starożytny w basenie Morza Śródziemnego w przekonaniu ówczesnych ludzi był wypełniony demonami: duchami dobrymi i złymi. Ich relacje do człowieka i z człowiekiem, podobnie jak i dzisiaj, wyznaczał światopogląd, lansowany przez grupy religijne i filozoficzne. Używam słowa "grupy”, bo świat starożytny pod tym względem był bardziej zróżnicowany z powodu mniejszych możliwości komunikacyjnych i wymiany myśli. Dotyczy to wszystkich aspektów życia ludzkiego: języka i sposobu myślenia, ubioru i dostępnej żywności, fauny i flory itd. W starożytności chrześcijańskiej w jakiejś mierze zasymilowano wspomniane

1 Ks. prof. dr hab. Arkadiusz Baron - dziekan Wydziału Teologicznego UPJPII (2014-); współtwórca serii „Myśl teologiczna” i współredaktor naukowy serii patrystycznej Źródła Myśli Teologicznej; autor m.in.: Spór o Pawła, spór o człowieka czy spór o Boga?, Kraków 1999; Neoplatońska idea Boga, Kraków 2005; Świętość a ideały człowieka, Kraków 2013; tłumacz komentarzy do listów Pawłowych (Ambrozjaster, Augustyn, Hieronim, Jan Chryzostom, Mariusz Wiktoryn, Pelagiusz) oraz dogmatycznych dokumentów soborowych (m.in. Soboru Trydenckiego i Watykańskiego I). Adres do korespondencji: ul. św. Marka 10/9, 31-012 Kraków. E-mail: arkadiusz.baron@upjp2.edu.pl. 
różne aspekty ludzkiego życia. W rezultacie powstała cywilizacja grecko-rzymska oparta symbolicznie na Atenach, Jerozolimie i Rzymie, która wpływa na życie ludzi w Europie, i nie tylko w Europie, do dziś, niosąc w sobie zarówno bogactwo, jak i ubóstwo wynikające z dokonanego synkretyzmu. Czasy nowożytne przyniosły nowe wyzwania związane z potrzebą integracji kultur jeszcze bardziej zróżnicowanych, bo obejmujących mieszkańców całej ziemi: od Europy poprzez Azję, Afrykę, aż do Ameryk. W Kościele procesy te nazwano inkulturacją. Następowały one od samego początku wszędzie tam, gdziekolwiek pojawiali się chrześcijanie. Nieśli oni w sobie nową siłę otwartą na każdego człowieka, niezależnie od jego światopoglądu. Za objawieniem Nowego Testamentu nazywamy ją Miłością, którą Jezus zostawił swoim uczniom w posłanym darze Ducha Świętego. To On jest gwarantem tożsamości chrześcijańskiej niezależnie od okoliczności, w jakich przychodzi żyć chrześcijaninowi.

Relacje człowiek-duch interesowały ludzi już w czasach przedchrześcijańskich i wyznaczały je poglądy antropologiczne. Od czasów Platona, a nawet wcześniej od Pitagorasa, w basenie Morza Śródziemnego wzrastał prymat wartości duchowych, który swoje apogeum osiągnął w I wieku przed Chrystusem i trwał w nurcie medio- i neoplatońskim przez następne wieki aż do czasów nowożytnych² ${ }^{2}$ Propagowane wówczas wartości duchowe z jednej strony wspierały ideał życia chrześcijańskiego, odrywając człowieka od życia tylko ziemskiego, ale z drugiej strony zagrażały ograniczaniem Ewangelii do spraw wyłącznie duchowych. Judaizm jeszcze bardziej zintegrował świat duchów z życiem ludzi. Duchy nie tylko zajmowały się człowiekiem, ale także mogły w nim zamieszkiwać3, jedne w celu współpracy z nim, inne w celu opętania go. Zetknięcie się tych dwóch koncepcji znalazło swoje konsekwencje w teologii Kościoła pierwotnego.

Wspomnijmy tylko o jednej w odniesieniu do relacji Syna Bożego z Jezusem z Nazaretu, dla zwerbalizowania której chrześcijaństwo

2 Por. A. Baron, Neoplatonizm a chrześcijaństwo w pierwszych wiekach, w: Wczesne chrześcijaństwo a religie, red. I. Ledwoń, M. Szram, Lublin 2012, s. 425-454.

3 Por. np. J. Daniélou, Teologia judeochrześcijańska, tłum. S. Basista, Kraków 2002, s. 199203: „Testament Judy mówi, że «dwa Duchy zajmują się człowiekiem, Duch prawdy i Duch kłamstwa» $(\mathrm{XX}, 1)$ ". 
zaproponowało ideę Wcielenia (sesarkomene, ensarkosis), a od IV wieku chrześcijanie grecko-języczni w obronie prawdziwego i pełnego człowieczeństwa Jezusa Wcielonego dodali termin „wczłowieczenie” (enantropesis). Dla myśli greckiej pierwotna chrystologia stanowiła problem, bo wcielenie ducha Osoby Syna Bożego w Jezusa z Nazaretu powinno skutkować powstaniem innego trzeciego bytu, jakiejś formy chimery. Oznacza to, że Chrystus byłby jakimś Bożo-Człowiekiem, czyli ani prawdziwym Bogiem, ani prawdziwym człowiekiem. Tymczasem chrześcijanie wyrażali swoją wiarę twierdząc, że Syn Boży po wcieleniu pozostaje prawdziwym Bogiem i prawdziwym człowiekiem. Ten chrystologiczny problem ostatecznie rozwiązał dopiero Sobór Chalcedoński w 451 roku oraz Sobór Konstantynopolitański III w $680 \mathrm{roku}^{4}$. W aspekcie niniejszego artykułu ważniejsze jest to, że w istocie swojej był to problem pneumatologiczny i to podwójnie pneumatologiczny. Po pierwsze dlatego, że należało się opowiedzieć za konkretną koncepcją relacji człowiek-duch. Po drugie dlatego, że Syn Boży jako Bóg jest nie tylko duchem, ale jest duchem świętym. Prawda ta również prowadziła do nieścisłości w werbalizowaniu treści pneumatologicznych, gdy próbowano określić, kim jest Duch Święty, a kim jest duch Jezusa, także święty.

Nie ułatwiał tego sposób pisania w starożytności wyłącznie majuskułą, a następnie minuskułą, brak spacji między wyrazami oraz stosowanie jedynie interpunkcji wyrazowej, która później praktycznie zanikła. Jest jeszcze jedna kwestia, której tutaj nie można pominąć, a mianowicie prawdopodobnie celowo nieprecyzyjna terminologia „ducha” była stosowana w starożytności zarówno w świecie semickim, jak i greckim i łacińskim. O nieprecyzyjnym, ale bardzo pojemnym i wieloznacznym pojęciu „ducha” wspomina Henryk Pietras, objaśniając Pawłowe słowa z Rz 8, 9-11: „Zauważmy jednak tylko to pomieszanie terminów: W człowieku może mieszkać Duch Boży, Duch Chrystusa, Chrystus, Duch tego, który wskrzesił Jezusa. Czy znaczy to, że dla Pawła terminy te były synonimami?”, i nieco dalej dodając: ,języki starożytne potrafiły być bardzo

4 Por. A. Baron, Głoszenie Chrystusa i jego recepcja w starożytności i dziś w aspekcie przepowiadanej treści, w: Głoszenie Pana Jezusa Chrystusa. Treść przepowiadania, red. H. Sławiński, Kraków 2017, s. 92-96 (Ancilla Verbi, 4). 
precyzyjne. Skoro zaś utrzymywali wieloznaczność, to pewnie dlatego, że zdawali sobie sprawę z ogromu daru, jakim jest Duch, z Jego przeróżnych form objawiania się" ${ }^{5}$. Innymi słowy, byli świadomi, że sprawy ducha przerastają możliwości poznawcze człowieka żyjącego w doczesności.

Nic więc dziwnego, że różnice w pojmowaniu ducha znalazły w starożytności swoje odzwierciedlenie także w języku. W języku hebrajskim słowo ruah (rodzaj żeński) oznacza ducha, a także: „podmuch”, „wiatr”, „odech”. „Ducha Świętego” (ruah haQodesh) rozumiano jako Moc Bożą, która może działać w człowieku, np. w proroku. Pojęcie to w judaizmie nie przeszło ewolucji takiej jak w chrześcijaństwie (J 1, 14: Słowo stało się ciałem, a nie duchem, ale ciałem, które wyraża całego człowieka). Po grecku „duch” oznaczany jest słowem pneuma (rodzaj nijaki), od pneō, „oddychać”, „tchnąć”, „mieć życie”, od którego pochodzi termin pneumatologia. Stąd „Ducha Świętego” jako Osobę Bożą wyrażano to pneuma to hagion. Jakkolwiek podobnie jak w języku hebrajskim słowo „duch” łączy się z tchnieniem, to jednak w świecie greckim, zwłaszcza pod wpływem myśli platońskiej, a w czasach chrześcijańskich - neoplatońskiej, wyrażającej się absolutnym prymatem ducha przeciwstawianego ciału, będzie promowało, a w każdym bądź razie dopuszczało, ograniczanie życia chrześcijańskiego wyłącznie do wymiaru duchowego. I wreszcie po łacinie słowo „duch” oddaje słowo spiritus (rodzaj męski) od spiro, „tchnąć”, „oddychać”, „wyziewać”, a „duch święty” to spiritus sanctus, a nie sacer

\section{Krótki zarys problematyki pneumatologicznej}

Krótką bibliografię patrystyczną dotyczącą Ducha Świętego podaje Franco Bolgiani ${ }^{7}$. Na początku XX wieku monografię o Duchu Świętym

5 H. Pietras, Początki teologii Kościoła, Kraków 2007, s. 249.

6 Krótkie omówienie terminologii związanej ze słowem „święty“ - por. A. Baron, Świętość a ideały człowieka, dz. cyt., s. 42-48. Np. różne znaczenia słów spiritus i pneuma u Ireneusza z Lyonu omawia B. Częsz, Związek Ducha Świętego z Kościołem w ujęciu świętego Ireneusza $i$ w interpretacji montanistycznej, dz. cyt., s. 55-69.

7 Por. Spirito Santo, w: Dicionario patristico e di antichità cristiane, vol. 2, a cura A. Di Bernardino, Casale Monferrato 1983-1988, kol. 3296-3298. 
napisał Henry Barclay Swete ${ }^{8}$, a pod koniec ubiegłego wieku czasopismo „Augustinianum” poświęciło tematyce pneumatologicznej obszerną część jednego ze swoich numerów ${ }^{9}$. Nowsze opracowanie pneumatologii w starożytności przedstawili Wolf-Dieter Hauschild i Volker Henning Drecoll $^{10}$. Zwięźle teologię Ducha Świętego w starożytności opracowali także polscy badacze: Henryk Pietras, Tadeusz Kołosowski, Bogdan Częsz i Józef Naumowicz ${ }^{11}$. Pietras wspomina o pismach judeochrześcijańskich (w tym także o Pasterzu Hermasa), gnostyckich, Justyna Rzymskiego, Ireneusza z Lyonu, Tertuliana, Orygenesa, Atanazego Wielkiego i Bazylego Wielkiego. Pomija Mariusza Wiktoryna, który w dyskusji o relacji Ojca i Syna jako jedyny wśród teologów swojego czasu w pełni włączył Osobę Ducha Świętego w sensu stricto trynitarne pojęcie Boga ${ }^{12}$.

Bibliografię opisową pneumatologii w ostatnich kilku dziesięcioleciach podaje prof. Giacomo Canobbio ${ }^{13}$. Ponadto, posiadamy obszerną antologię tekstów o Duchu Świętym, którą wydał Gerardo Di Nola ze wstępem Lorenzo Dattrino ${ }^{14}$. W ostatnich latach ukazały się podręczniki pneumatologii ${ }^{15}$, pojawiły się dzieła o „Odnowie w Duchu Świętym” 16

8 H. B. Swete, The Holy Spirit in the Ancient Church, London 1912.

9 Por. „Augustinianum” 20 (1980) n. 3, s. 429-686.

10 Por. Pneumatogie In der Alten Kirche, Bern 2004.

11 Por. H. Pietras, Początki teologii Ducha Świętego, w: Św. Atanazy Wielki, Listy do Serapiona, Kraków 1996, s. 5-67 (ŹMT, 2); H. Pietras, Początki teologii Kościoła, dz. cyt., s. 247286; T. Kołosowski, Nauka Ojców Kościoła o Duchu Świętym. Wybrane zagadnienia, „Seminare” 13 (1997), s. 249-267; B. Częsz, Duch Święty został nam dany. Nauczanie Ojców i wiara starożytnego Kościoła, Gniezno 1998; J. Naumowicz, Wstęp, w: Św. Bazyli Wielki, O Duchu Świętym, dz. cyt., s. 5-77.

12 Por. A. Baron, Mariusz Wiktoryn - człowiek ijego dzieło. Wprowadzenie do dzieł egzegetycznych, Kraków 1999, s. 39-40 (ŹMT, 13); M. Simonetti, La crisi ariana nel IV secolo, Roma 1975, s. 293.

13 Por. http://www.teologiamilano.it/teologiamilano/allegati/614/08_pneumatologia. pdf (18.03.2019).

14 Lo Spirito Santo nella testimonianza dei Padri e degli Scrittori cristiani, Secoli I-V, ed. G. Di Nola, Roma 1999, podaje fundamentalne teksty patrystyczne od Klemensa Rzymskiego do Leona Wielkiego o Duchu Świętym ze wstępem L. Dattrino, który omawia pneumatologię pierwszych czterech wieków.

15 Por. F. Lambiasi, D.Vitali, Spirito Santo. Mistero e presenza. Per una sintesi di pneumatologia, Bologna 2005.

16 Por. np. Verso una nuova età dello Spirito. Filosofia, teologia, movimenti,, a cura di G. Colzani, Padova 1997 (Studi religiosi). 
oraz o ponownym jego odkryciu ${ }^{17}$, o życiu w Duchu Świętym ${ }^{18}$. Obecnie tematyka związana z Duchem Świętym interesuje oprócz teologów, także filozofów i religioznawców ${ }^{19}$. Homiletów zapewne zainteresuje zbiór siedemnastu artykułów, wydanych przez Achillę Marię Triaccę, a które dotyczą m.in. liturgii, sakramentu pokuty, sakramentu święceń oraz homilii ${ }^{20}$.

Obecnie ujęcia pneumatologii obejmują: osobowość, bóstwo, atrybuty, działanie i symbole Ducha Świętego w Starym i Nowym Testamencie, u ojców Kościoła, w różnych odłamach chrześcijaństwa aż po czasy współczesne. Daje temu świadectwo Jan Paweł II, który roli Ducha Świętego w życiu Kościoła i świata poświęcił encyklikę Dominum et Vivificantem w maju 1986 roku. Pisze w niej o działaniu Ducha Świętego od początku ludzkości, odwołując się przede wszystkim do świadectw biblijnych i patrystycznych, chociaż do Pasterza Hermasa nie znajdujemy żadnych odniesień.

W starożytności chrześcijanie podejmowali nurtujące ich wspólnoty problemy dotyczące wiary. Kwestię Ducha Świętego rozpatrywano oficjalnie dopiero na synodach w IV wieku ze szczególnym uwzględnieniem Jego bóstwa. Jednakże opinie, że wspólnota kościelna zaczęła się interesować Osobą Ducha Świętego dopiero w IV wieku, trudno uznać za prawdziwe. Rzeczywiście w IV wieku toczono spory o Jego bóstwo i równość

17 Por. A. Moda, Lo Spirito Santo. Alcune piste di riflessione nella teologia sistematica cattolica a partire dal Vaticano II, Torino 2012 (z bibliografią dotyczacą różnych aspektów tej problematyki).

18 La vita nello Spirito, a cura di G. Canobbio, F. Dalla Vecchia, R. Tononi, Brescia 2012 (Quaderni Teologici del Seminario di Brescia, 22). Jest to zbiór artykułów na różne interesujące nas tematy (Duch a Mądrość w Księdze Mądrości; rola Ducha Świętego w życiu chrześcijanina w ujęciu Bazylego Wielkiego; gdzie i jak Duch Święty działa poza Kościołem relacja świętości i teologii według H. U. von Balthasara, analiza kantaty Jana Sebastiana Bacha na uroczystość zesłania Ducha Świętego i wiele innych).

19 Por. Lo Spirito. Percorsi nella filosofia e nelle culture, a cura di M. Pagano, Milano-Udine 2011. W dziele omówione są kultury starożytne (chińska, indyjska, hebrajska i grecka), pisarze średniowieczni (Joachim da Fiore, Bonawentura, Tomasz z Akwinu, Eckhart, Mikołaj z Kuzy) oraz dziesiątki autorów nowożytnych i współczesnych (np. Fichte, Hegel, Schelling, Kierkegaard, Dilthey, Troeltsch, Scheler, Bergson, Heidegger, Ricœur, Derrida, Sołowiew, Florenskij).

20 Por. A. M. Triacca, Lo Spirito Santo nella liturgia e nella vita della Chiesa, Città del Vaticano 2011. 
z Osobą Syna Bożego m.in. przeciwko macedonianom, ale dyskusja ta wypływała z wcześniejszych sporów chrystologicznych i trynitarnych. Nie oznacza to jednak, że wiara pierwotnego Kościoła nie dotyczyła Osoby Ducha Świętego. Pojawienie się tego typu opinii staje się zrozumiałe, gdy zauważy się, że pneumatologia Nowego Testamentu i Kościoła pierwotnego jest w swojej istocie chrystologiczna. Idzie jednak o to, aby nie kształtować jej w kierunku chrystomonicznym. Dotyczy to zwłaszcza teologii zachodniej, którą przed zarzutami chrystomonizmu bronił Yves Congar $^{21}$. Trudno się nie zgodzić z twierdzeniem, że Ewangelie omawiają życie Jezusa w aspekcie pneumatologicznym: od poczęcia „w Duchu Świętym", przez chrzest, zmartwychwstanie, wniebowstąpienie aż po zesłanie Ducha Świętego.

W rozwój pneumatologii w starożytnym Kościele wpisało się wiele osób różnej proweniencji. W ujmowaniu relacji Ojciec-Syn-Duch Święty przydatne okazały się słowa Pseudo-Platona z Listu 2, 312 E (Pierwszy Bóg; Drugi Bóg; Trzeci Bóg) oraz Platona z Timaiosa 36 B-C. Do ważniejszych z pisarzy chrześcijańskich należeli: Justyn Rzymski (Apologia I, 60, 5-9; I, 61) łączący pojmowanie Ducha z Rdz 1, 2 i przedstawiający Go jako Ducha przemawiającego przez proroków; Tacjan (Orationes 13, 3), który mówi o Duchu jako cierpiącym diakonie Boga; Teofil z Antiochii (Do Autolyka 2, 15), dla którego Duch jest trzecim bytem Bożym utożsamianym z Mądrością Bożą i Jego mocą. Więcej na temat Ducha Świętego dowiadujemy się od Ireneusza z Lyonu z jego Wykładu nauki apostolskiej 5. 10. $49^{22}$ oraz z Adversus haereses IV, 7, 4 (Duch progenies Ojca); IV, 20. 33; V, 9. $12^{23}$. Ponadto, Ireneusz dostarcza nam wiedzy na temat pojmowania Ducha w systemach gnostyckich ${ }^{24}$. Tertulian pisze o Duchu Świętym w kontekście sporów trynitarnych i uważa Go za trzecią Osobę Bożąa ${ }^{25}$,

21 Por. Y. Congar, Credo nello Spirito Santo, Brescia 1998 (passim).

22 Kraków 1997, 7, 27. 32 (Źródła Myśli Teologicznej [dalej: ŹMT], 7).

${ }_{23}$ Szerzej na ten temat - por. B. Częsz, Związek Ducha Świętego z Kościołem w ujęciu świętego Ireneusza i w interpretacji montanistycznej, Poznań 1991.

24 Por. Epifaniusz z Salaminy, Panarion: herezje 1-33, tłum. M. Gilski, Kraków 2015, s. 423515, gdzie cytowane są teksty Ireneusza z Adversus haereses.

${ }_{25}$ Tertulian, Przeciw Prakseaszowi 30, 5: „zesłał dar otrzymany od Ojca, Ducha Świętego, trzecią osobę Bóstwa i trzecie stanowisko Boskiego majestatu”, tłum. E. Buszewicz, w: Trójca Święta, wprow. i oprac. H. Pietras, Kraków 1997, s. 86 (ŹMT, 4). 
która jest „vicaria vis” Syna ${ }^{26}$. „Osoba” oddaje tu łacińskie słowo persona, które jest terminem technicznym Tertuliana, unikającego słów hipostaza i ousia, które jego zdaniem odnoszone do Boga prowadzą do trytei$\mathrm{zmu}^{27}$. Pod tym względem podobne stanowisko prezentuje Hipolit ${ }^{28}$. Dla Orygenesa Duch Święty jest z natury swej święty, a wszelkie inne istoty „uświęcenie swoje zawdzięczają przyjęciu Jego lub Jego natchnienia”29, ponieważ „uświęcanie jest właściwością Ducha Świętego, nie związaną, a w każdym razie różną od działalności stwórczej Boga i udzielania przez Niego dóbr naturalnych"30. Uświęcającą rolę Ducha Świętego w myśli Orygenesa podkreśla także Pietras ${ }^{31}$. Według Orygenesa Biblia nie rozstrzyga wielu kwestii pneumatologicznych. Jego zdaniem apostołowie pouczyli, „że Duch Święty jest zjednoczony z Ojcem i Synem w chwale i godności; nie rozstrzygnięto wyraźnie, czy Duch jest zrodzony, czy nie zrodzony oraz czy i On ma być uważany za Syna Bożego, czy nie"32. Orygenes, wielki komentator Biblii, nie rozstrzyga tu tej kwestii, ale jest dla nas świadkiem problemów, na jakie natrafiali teologowie w jego czasach.

W dziejach chrześcijaństwa zdarzały się okresy, w których obserwujemy szczególne ożywienie pentekostalne. Jednym z pierwszych był montanizm z II wieku, zwany „nowym proroctwem”33, od Montana (ok. 155160), który wystąpił we Frygii jako głos Ducha Świętego $0^{34}$. O montanizmie

26 Tertuliani, Liber de praescriptionibus adversus haereticos, 13, 5, in: Tertuliani Opera omnia, tomus secundus, accurante J.-P. Migne, Parisiis 1844, col. 9-74 (Patrologiae Cursus Completus. Series Latina, 2).

27 Por. H. Pietras, Wprowadzenie, w: Trójca Święta, dz. cyt., s. 20-21 (ŹMT, 4).

28 Por. Hipolit, Przeciw Noetosowi 14, s. 97 (ŹMT, 4), gdzie mówi o osobach (greckie to prosopon, czyli twarz, osoba).

${ }_{29}$ Orygenes, O zasadach, I, 8, 3, s. 127 (ŹMT, 1). Szerzej na ten temat por. A. Baron, Świętość a ideały człowieka, dz. cyt., s. 285-293.

30 A. Baron, Świętość a ideały człowieka, dz. cyt., s. 292.

31 Por. H. Pietras, Początki teologii Kościoła, dz. cyt., s. 275-283 z krótką bibliografią na s. 283.

32 Orygenes, O zasadach, Przedmowa 4, tłum. i oprac. S. Kalinkowski, Kraków 1996, s. 53 (ŹMT, 1). Problem podejmowany przez Hermasa w Pasterzu 58, 2.

33 Euzebiusz z Cezarei, Historia kościelna, V, 19, 2, tłum. A. Caba, A. Lisiecki, Kraków 2013, s. 355 (ŹMT, 70).

${ }^{34}$ Por. Euzebiusz z Cezarei, Historia kościelna, V, 14-19, dz. cyt., s. 338-355 (ŹMT, 70). 
szerzej pisze ks. Jan Słomka ${ }^{35}$. Ten ruch interesuje nas dlatego, że zrodził się w czasach powstania Pasterza, wprawdzie na Wschodzie, ale szybko się rozprzestrzenił na Zachód.

$\mathrm{Na}$ inne problemy pneumatologiczne natrafia teolog zajmujący się jedną z najdłuższych kontrowersji dotyczących Ducha Świętego - swoimi korzeniami sięgającą czasów patrystycznych - popularnie zwaną sporem o filioque ${ }^{36}$. Na temat jego dyskusji - 1000 lat później - Sobór we Florencji poświęcił setki stron ${ }^{37}$.

Obecne zainteresowanie Duchem Świętym pozostaje w związku $\mathrm{z}$ wielkim rozwojem pneumatologii, który nastąpił $\mathrm{w}$ drugiej połowie XX wieku, zwłaszcza w teologii protestanckiej ${ }^{38}$ oraz we wspólnotach pentekostalnych. W związku z doświadczeniami przeżytymi w zetknięciu się z nimi miliony osób na całym świecie przyjęły chrześcijaństwo w XX wieku. Wiąże się z tym „indygenizacja” Ewangelii w różne kultury oraz związany z nią rozwój nowych ujęć, dotyczących rozumienia Ducha. Dało temu wyraz Siódme Zgromadzenie Ogólne Światowej Rady Kościołów w Canberze (Australia) w lutym 1991 roku pt. Vieni, Spirito Santo, rinnova l'intera creazione!, zapewne nawiązującym do modlitwy Jana Pawła II w Polsce, która była wołaniem do Ducha Świętego o odnowienie „tej ziemi”. Jedną z dwóch relacji wprowadzających przedstawiła teolożka prezbiteriańskiego Kościoła Koreanka Chung Hyun Kyung. W swojej prezentacji, odnoszącej się do problematyki Ducha Świętego, zastosowała zupełnie nowe terminy, które korelowały z jej środowiskiem

35 J. Słomka, Nowe proroctwo. Historia i doktryna montanizmu, Katowice 2007.

36 Por. moje uwagi do mojego przekładu Bulli unii z Grekami (Laetentur caeli) Soboru we Florencji, w: Dokumenty Soborów Powszechnych, tekst łaciński, grecki, arabski, ormiański, polski, t. 3, oprac. A. Baron, H. Pietras, Kraków 2004, s. 458-477 (zwłaszcza noty 15 i 16 na s. 464-465).

37 Por. Concilium Florentinum. Documenta et Scriptores, Pontificium Institutum Orientalium Studiorum, Roma 1940nn. Dyskusja soborowa na temat pochodzenia Ducha Świętego znajduje się w: Concilium Florentinum. Documenta et scriptores, vol. 6, series B, Roma 1955, s. 134-224; por. także G. Bessarione, E. Candal, De Spiritus Sancti processione ad Alexium Lascarin Philanthropinum, Roma 1961, series 2B (Concilium Florentinum, 7).

38 Por. np. W. Welker, Gottes Geist. Theologie des Heiligen Geistes, Neukirchen-Vluyn 1993; J. Moltmann, Lo Spirito della vita. Per una pneumatologia integrale, Brescia 1994. 
kulturowym, ale równocześnie wzbudziły sprzeciw uczestników ${ }^{39}$, pociągając za sobą negatywną ocenę teologiczną jej wystąpienia oraz stwierdzenie, że tego typu problemów można uniknąć przez integralne ujmowanie pneumatologii wraz z chrystologią i teologią trynitarną ${ }^{40}$.

Ten krótki zarys problematyki pneumatologicznej wraz z uwagami wprowadzającymi dobitnie pokazuje, jak problemy związane z rzeczywistością określaną słowem „duch” od zarania dziejów wynikały i zależały od języka, w którym próbowano je werbalizować. Zarzuty o nieprecyzyjny język, jak i o synkretyzm niczego nie wnoszą w chrześcijański trud misyjny inkulturowania prawd wiary, a nawet mogą mu szkodzić, rodząc nadzieje na jednoznaczne ich rozwiązanie. Tymczasem Jezus wprost kierował do swoich uczniów słowa, że "gdy przyjdzie On, Duch Prawdy, doprowadzi was do całej prawdy" (J 16,13). W ten sposób Jezus

39 Por. Chung Hyun Kyung, https://en.wikipedia.org/wiki/Chung_Hyun_Kyung. Oskarżana o synkretyzm odpowiedziała: „If they ask me, «Are you a syncretist?» I say, «You are right, I am a syncretist, but so are you.» My response is that I know I am a syncretist, but you don't know you are a syncretist because you have hegemonic power... non-Christian cultures, when they try to interpret the gospel out of their life experience, they are syncretists! But they are just being true to their identity, history and culture".

40 Por. M.E. Putney, Come, Holy Spirit, renew the whole Creation: seventh assembly of the World Council of Churches, „Theological Studies” 52 (1991), s. 629: „This was the most controversial presentation at the assembly and required the programming of an additional plenary to deal with the debate it caused, especially the claim that it was syncretistic. Chung Hyun-Kyung had begun her presentation by calling into the assembly various spirits, e.g., the spirit of Hagar, the spirit of male babies killed by Herod, the spirit of victims of the Crusades, the spirit of Jewish people killed in the Holocaust, the spirit of earth, air, and water raped, tortured and exploited by human greed. It was these last spirits that the Orthodox statement singled out. Her argument was that, in her Korean understanding, these spirits were full of han or anger. They need to be listened to if we are to right the wrongs that have made them victims. «Without hearing the cries of these spirits, we cannot hear the voice of the Holy Spirit... For us they are the icons of the Holy Spirit who became tangible and visible to us». [...] First, the Orthodox expressed concern that there was a too easy attribution to the Holy Spirit of the authorship for diverse movements and developments which could also be the result of the spirit of the world or one's personal spirit, given the reality of sin and error in all human activity. This was more than an issue of discernment, though it certainly was that. Just as ecclesiological documents in the past too easily relegated the work of the Holy Spirit to an unexplained adverbial phrase, «through the Holy Spirit», so there was a tendency in Canberra, when addressing justice issues, to place the Holy Spirit as the subject of sentences, equally without explanation, e.g. [...] Only by linking pneumatology to Christology and ecclesiology in a truly trinitarian theology can such facile claims be avoided". 
prawdopodobnie dał swoim uczniom znak, że prawdę o Bogu będzie głosił sam Duch Święty, który „powie wszystko... i oznajmi rzeczy przyszłe” $(J 16,13)$ ludziom niezależnie od ich języka, kultury i cywilizacji.

\section{Dzieło, struktura i tematyka Pasterza Hermasa}

Pasterz Hermasa należy do pism judeochrześcijańskich. Dla uściślenia dodajmy, że „judeochrześcijaństwo" rozumiemy tu w trzecim znaczeniu tego słowa podanym przez Jeana Daniélou, jako „pewną formę chrześcijańskiej myśli, która nie implikuje związku ze wspólnotą żydowską, ale która wyraża się w ramach zapożyczonych z judaizmu". Idzie więc o ,judeochrześcijaństwo chrześcijan pochodzących z judaizmu, ale także tych nawróconych z pogaństwa" ${ }^{41}$. Daniélou uważa Pasterza za ,jedno z fundamentalnych dzieł dla poznania judeochrześcijańskiego środowiska teologicznego i duchowego" 42 . W swojej monografii prezentuje szeroki kontekst myśli judeochrześcijańskiej: środowisko intelektualne, doktryny i instytucje. W każdej z tych części nawiązuje do kwestii rozumienia świata duchów i do Pasterza Hermasa ${ }^{43}$, które to dziełko zostaje ukazane w odniesieniu do szerokiej spuścizny literackiej judeochrześcijaństwa. Dlatego można ją uznać za niezwykle cenną w aspekcie lektury samego Pasterza.

Pasterz Hermasa był znany w starożytności chrześcijańskiej i cieszył się wielkim autorytetem m.in. dlatego, że lokalnie uważany był za część Nowego Testamentu. Jeszcze w V wieku papież Gelazy (492-496) uznał za konieczne wymienić je wśród apokryfów, aby nie było czytane w czasie liturgii ${ }^{44}$.

\footnotetext{
41 J. Daniélou, Teologia judeochrześcijańska, dz. cyt., s. 21.

${ }^{42}$ J. Daniélou, Teologia judeochrześcijańska, dz. cyt., s. 51.

43 Duchom poświęca rozdziały i podrozdziały - por. J. Daniélou, Teologia judeochrześcijańska, dz. cyt., s. 148-154 (angelologia); s. 154-160 (demonologia); s. 175-204 (Trójca i angelologia, w tym podrozdziały: Duch Święty i Gabriel oraz Duch Święty i Książę światłości); s. 408-413 (dwa duchy).

${ }_{44}$ Por. Synod w Rzymie w 494/495 roku, w: Dokumenty synodów od 431 do 504 roku, układ i oprac. A. Baron, H. Pietras, Kraków 2011, s. 321, w. 29 (Synodi et Collectiones Legum, 6).
} 
Dzieło oryginalnie, powstałe w języku greckim, już w starożytności tłumaczono na inne języki. Zachował się przekład łaciński z końca II wieku, a więc Pasterz jest jednym z najstarszych dzieł chrześcijańskich w języku łacińskim. Ponadto, zostały ocalone fragmenty przekładów na język koptyjski z kodeksów z IV i z V wieku, a także cały, ale późniejszy i zniekształcony, przekład na język etiopski oraz małe fragmenty z przekładu na język perski ${ }^{45}$.

W późniejszych wiekach dzieło było znane jedynie z cytatów zawartych w pismach pisarzy chrześcijańskich. W 1513 roku na nowo zostało odkryte i opublikowane w wersji łacińskiej, a w 1859 wydane w wersji greckiej, odnalezionej na wyspie Athos. Do naszych czasów Pasterz doczekał się wielu wydań krytycznych, przekładów na języki nowożytne oraz setki opracowań, to jednak brakuje wyczerpującej monografii dotyczącej pneumatologii i jej terminologii w tym dziełku ${ }^{46}$, poza kilku artykułami, na które wskazujemy poniżej w punkcie 3.

Na ogół przyjmuje się, że Pasterz ma jednego autora, ale nie wiadomo, kto nim jest. Zdaniem Orygenesa był to człowiek z kręgu św. Pawła wspomniany w Rz 10, 31. Aleksandryjczyk komentuje to słowami: „Moim zdaniem ów Hermas jest autorem książeczki pt. Pasterz, które to pisemko uważam za bardzo pożyteczne i natchnione przez Boga” ${ }^{47}$. Podobną opinię znajdujemy u Euzebiusza z Cezarei ${ }^{48}$. Tzw. fragment Muratoriego za autora Pasterza uważa Hermasa, brata papieża Piusa I, który

45 Por. F. Szulc, Syn Boży w „Pasterzu” Hermasa. Świadectwo chrystologii judeochrześcijańskiej, Katowice 2006, s. 17-19 (Studia Antiquitatis Christianae, Series Nova, 2); M. Starowiejski, Pierwsi świadkowie. Wybór najstarszych pism chrześcijańskich, Kraków 1998, s. 209 ( BOK, 10).

46 Por. F. Szulc, Syn Boży w „Pasterzu” Hermasa..., dz. cyt., s. 20-22. 177-189 (bibliografia: tekst Pasterza, tłumaczenia, opracowania); J. Quasten, Patrologia, t. 1, Casale Monferato 1983, s. 99-100; Hermas, Le Pasteur, Paris 1968 (Sources Chrétiennes, 53bis), tłum. A. Świderkówna, Pasterz, Warszawa 1990, s. 135-211 (Pisma Starochrześcijańskich Pisarzy, 45); wyd. II uzup. i popr. przekład w: Pierwsi świadkowie. Wybór najstarszych pism chrześcijańskich, Kraków 1998, s. 211-299 (Biblioteka Ojców Kościoła [dalej: BOK], 10), z którego korzystamy w obecnym artykule (ed. J. P. Migne, Paris 1857-1866, kol. 871-1011 [Patrologiae cursus completus. Series Graeca, 2]; inny polski przekład: A. Lisiecki, Poznań 1924, s. 280-446 [Pisma Ojców Kościoła, 1]).

47 Orygenes, Komentarz do „Listu świętego Pawła do Rzymian, 10, 31, cz. 2, tłum. S. Kalinkowski, Warszawa 1994, s. 546 (Pisma Starochrześcijańskich Pisarzy, 57).

${ }_{48}$ Por. Historia kościelna III, 3, 6, dz. cyt., s. 143 (ŹMT, 70). 
był biskupem Rzymu w połowie II wieku. W XIX wieku w debacie o autorstwie Pasterza pojawiły się opinie o dwóch, o trzech autorach tego dziełka, a nawet o czwartym, pełniącym rolę redaktora. Szczegółowe badania języka i terminologii pozwoliły wyodrębnić w tekście wiele hebraizmów i zakwestionować twierdzenie, że ojczystym językiem jego autora był język grecki ${ }^{49}$.

Podobnie przedstawia się sytuacja w odniesieniu do czasu powstania dziełka, które jest datowane na lata pomiędzy 60 a 160 rokiem. Franciszek Szulc stwierdza, że można przyjąć pierwszą połowę II wieku za najbardziej prawdopodobny czas jego powstania ${ }^{50}$.

Jeśli idzie o miejsce powstania, to badacze są zgodni, że Pasterz powstał „w Rzymie w pierwszej połowie II wieku, a jego potencjalnymi adresatami są wszyscy w Kościele" ${ }^{51}$.

Złożona struktura tekstu zdaje się potwierdzać, że Pasterz w obecnie znanej nam wersji powstawał etapami (nawet jeśli może mieć jednego autora i tego samego lub innego redaktora) od czasów Klemensa Rzymskiego aż do drugiej połowy II wieku. Szulc przyjmuje powszechnie akceptowany podział tekstu na dwie części: Księga wizji (1-24) oraz Księga Pasterza (25-114), a w odniesieniu do gatunku literackiego podziela stwierdzenie, że nie jest to apokalipsa, ani księga alegorii, ale stanowi dzieło literackie suigeneris ${ }^{52}$.

Hermas podejmuje w Pasterzu problem powrotu do łaski utraconej po chrzcie, zapożyczony zdaniem Daniélou ze zwyczajów Kościoła judeochrześcijańskiego ${ }^{53}$. Grzesznik ma wówczas w jego opinii możliwość

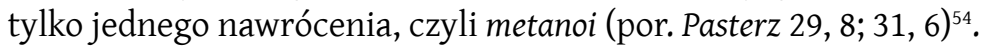

\footnotetext{
49 Dyskusje na ten temat - por. F. Szulc, Syn Boży w „Pasterzu” Hermasa, dz. cyt., s. 53-60.

50 Dyskusje na ten temat - por. F. Szulc, Syn Boży w „Pasterzu” Hermasa, dz. cyt., s. 59-65.

51 F. Szulc, Syn Boży w „Pasterzu” Hermasa, dz. cyt., s. 67 oraz por. M. Starowiejski, w: BOK, 10, nota 4, s. 209.

52 Por. F. Szulc, Syn Boży w „Pasterzu” Hermasa, dz. cyt., s. 23. 29.

53 Por. J. Daniélou, Teologia judeochrześcijańska, dz. cyt., s. 79.

54 Termin metanoia w Pasterzu Hermasa por. A. Baron, Świętość a ideały człowieka, dz. cyt., s. 217-222; F. Szulc, Syn Boży w „Pasterzu” Hermasa, dz. cyt., s. 33-47.
} 


\section{Duch Święty a inne duchy w Pasterzu}

Świat w Pasterzu jest pełen duchów świętych, aniołów i duchów złych (np. anioł chwały, pokuty, czyli nawrócenia, kary, sprawiedliwości i zła) ${ }^{55}$, na określenie których stosuje zwykle greckie słowo pneuma, ale nie obcy mu jest także termin daimonion (por. Pasterz 27, 3; 100, 5). Demon oznacza tu, podobnie jak i w Nowym Testamencie, duchy złe. Pneumatologią Pasterza Hermasa w aspekcie ogólnym zajmowali się m.in. John Percival Martin, Cornelis Haas oraz Nadia Ibrahim Fredrikson ${ }^{56}$. Fredrikson prezentuje pneumatologię Pasterza jako zależną od poglądów wspólnoty Quamran i jej dualizmu etyczneg ${ }^{57}$. Pojęcia dualizmu w judaizmie i wspólnocie Quamran nie należy jednak łączyć z dualizmem ontycznym ${ }^{58}$.

Hermas stosuje w Pasterzu słowo pneuma ponad sto razy w różnych znaczeniach, czasem niełatwych do jednoznacznego określenia. Dodatkowo rozumienie tego słowa w konkretnym miejscu utrudnia fakt, że w starożytności nie rozróżniano dużych i małych liter, o czym wspomnieliśmy powyżej, ale pisano albo majuskułą albo minuskułą. Jest to o tyle ważne, że współczesny posiadany przez nas tekst krytyczny Pasterza, rozróżniając duże i małe litery, stanowi już jego interpretację i nie można o tym zapominać. Manlio Simonetti pisze, że w niejednym przypadku nie jest łatwo określić zakres treściowy używanego przez Hermasa słowa pneuma, nawet jeśli odnoszone jest ono do Chrystusa, bo albo wskazuje na naturę Chrystusa, albo na Jego preegzystującą Osobę, albo

55 Angelologia według Pasterza - por. E. Staniek, Angelologia w „Pasterzu” Hermasa, „Studia Theologica Varsaviensia” 9 (1971) nr 1, s. 51-82.

56 Por. L. Cirillo, La christologie pneumatique de la cinquième parabole du „Pasteur" d'Hermas (Par. V, 6, 5), „Revue de l'histoire des religions” 184 (1973), s. 25-48; J. P. Martin, Espíritu y dualismo en el Pastor de Hermas y su relación con el judaísmo, „Vetera Christianorum” 15 (1978), s. 295-345; C. Haas, Die Pneumatologie des Hirten des Hermas, w: Aufstieg und Niedergang der Römischen Welt, Hrsg. W. Haase, Teil 2, Bd. 27/1, Berlin-New-York 1993, s. 552-586; N. I. Fredrikson, L'Esprit Saint et les esprits mauvais dans le Pasteur d'Hermas: Sources et prolongements, „Vigiliae Christianae” 55 (2001), s. 262-280.

57 Pogląd taki zdaje się potwierdzać Daniélou, według którego Hermas wywodzi się z essenizmu (por. Teologia judeochrześcijańska, dz. cyt., s. 79). Związki esseńczyków i wspólnotą Qumran - por. J. Maier, Między Starym a Nowym Testamentem, tłum. E. Marszał, J. Zakrzewski, Kraków 2002, s. 315-329.

58 Por. J. Maier, Między Starym a Nowym Testamentem, dz. cyt., s. 32-33 wraz z notami. 
służy do utożsamienia Osoby Syna Bożego z Duchem Świętym ${ }^{59}$. Ostatnią część wypowiedzi Simonettiego omawiamy w następnym punkcie.

Dla zobrazowania roli pełnionej przez duchy w Pasterzu przypomnijmy słowa Hermasa, który pisze, że duch go porwał i poniósł przez bezdroża (por. Pasterz 1, 3; 5, 1); że złym zamysłem i ogłupiającym dla ducha, który jest już święty i wypróbowany, jest pożądanie rzeczy złej (por.Pasterz 2,4); że brak troski i wątpliwości prowadzą do starzenia się ducha (por. $P a-$ sterz 19, 2), a nawrócenie (metanoia) go odmładza (por. Pasterz 21, 2. 4).

Ideę starzenia się ducha jako owocu grzechów i odmładzania w rezultacie nawrócenia ilustrują trzy kobiety: sędziwa i siedząca, młoda i stojąca oraz młoda, piękna i wesoła (Pasterz 18 - 21). Pierwsza ilustruje ducha zestarzałego i słabego; druga jest odmłodzona duchem i umocniona wiarą, trzecia z młodniejącym i radosnym duchem jest osobą nawróconą z całego serca. Hermas rozumie nawrócenie (grecka metanoia, czyli przemiana sposobu myślenia) jako odmładzanie ducha.

W duchu żyjemy więc od starości do dziecka (por. Mt 18, 3: „Jeśli się nie odmienicie i nie staniecie jak dzieci, nie wejdziecie do królestwa niebieskiego"), oczywiście od starości grzechu do dziecka Bożego. Hermas mówi o tym expressis verbis pod koniec swojego dzieła bez odniesienia do ducha: „Z dwunastej, białej góry przychodzą tacy oto wierzący: są oni jak niemowlęta, z których serca nie wypływa żadne zło ani też nie poznali czym jest zło, ale pozostają w całkowitej niewinności" (Pasterz 106, 1) i dalej nawiązuje do Mt 18, 2-5.

Trwanie w duchu nawrócenia wymaga cierpliwości, której obcy jest wszelki gniew. „Jeśli będziesz cierpliwy - pisze Hermas - Duch Święty mieszkający w tobie nie dozna skalania, bo nie przysłoni Go inny duch zły..., gdy się zdarzy wybuch gniewu, od razu Duch Święty, jako że jest delikatny, odczuwa ciasnotę, brak czystej przestrzeni i stara się to mieszkanie opuścić. Dławiony przez ducha złego, nie znajduje miejsca, aby służyć Bogu... jeśli więc te dwa duchy mieszkają razem, jest to złe i szkodliwe dla człowieka, w którym mieszkają" (Pasterz 33, 2-4).

59 Por. M. Simonetti, Note di cristologia pneumatica, „Augustinianum” 12 (1972) n. 2 s. 203: ,alcune volte il termine pneuma, in riferimento a Cristo, indica la sua natura divina; altre volte indica la persona del Cristo preesistente; altre volte in questo senso giunge ad identificare il Cristo preesistente con lo Spirito santo". 
Zapewne Hermas przestrzega w ten sposób człowieka ochrzczonego, który zdradza ideały chrześcijańskiego życia. Ponadto, przytoczone słowa mogą nasuwać błędne wnioski, że Duch Święty jest słaby w porównaniu ze złym duchem. Tymczasem Hermas stwierdza tylko, że jest delikatny, że jest mu ciasno w sercu człowieka źle postępującego, że w takiej sytuacji nie znajduje możliwości służenia Bogu, że chce opuścić takie mieszkanie. Należy podkreślić, że nie czyni tego z własnej inicjatywy, ale jedynie dostosowuje się do stanu danego człowieka i jego życiowych decyzji. Następne fragmenty nie pozostawiają w tym względzie żadnych wątpliwości. Hermas pisze, że „wątpliwość jest duchem z ziemi rodem, pochodzącym od szatana, a mocy nie ma żadnej” (Pasterz 39, 11). Ponadto, „smutek jest najgorszy ze wszystkich duchów... wypędza Ducha Świętego, a potem zbawia" (Pasterz 40, 2-3). Wątpliwość tłumaczy tu słowo dipsychía, która nie oznacza wątpliwości dogmatycznej, ale brak zaufania i zwątpienie jako przeciwieństwo wiary, zawierzenia i zaufania ${ }^{60}$. Słowo to może oznaczać także obłudę, formę dwulicowości (dosłownie: dwu-duchowości), krótko mówiąc wszelkie formy nieszczerości, zakłamania i hipokryzji, z którymi Duch Święty nie ma nic wspólnego.

Nasuwa się pytanie, jak smutek może wypędzać Ducha Świętego, a następnie prowadzić do zbawienia? (por. Pasterz 40, 2; 41, 1). Zdaniem Hermasa dzieje się tak dlatego, że smutek grzechu zasmuca i wypędza Ducha Świętego, a jeśli następnie pojawi się smutek-żal za popełniony grzech, to ów smutek na powrót przynosi zbawienie (por. $\mathrm{Pa}$ sterz 41,1-5) i radość (por. Pasterz 42, 1. 4). „Odrzuć od siebie smutek i nie skąp miejsca mieszkającemu w tobie Duchowi Świętemu... Duch Boży dany twemu ciału nie znosi ani smutku, ani ciasnoty" (Pasterz 41, 5-6). Jak mówi polskie przysłowie: „Smutny święty, to żaden święty”. Hermas wyraźnie stwierdza, że „człowiek smutny... zasmuca Ducha Świętego... zasmucając Ducha Świętego popełnia niegodziwość... smutek zmieszany z Duchem Świętym sprawia, że modlitwa nie ma już tej samej mocy (Pasterz 42, 2-3). Na szczególną uwagę zasługują tu słowa Hermasa o stałej obecności Ducha Świętego, nawet wówczas gdy zostaje zasmucony czynami człowieka.

60 Por. BOK 10, nota 99, s. 296. 
Łatwo zauważyć, że przytoczone fragmenty niekoniecznie mówią o Osobie Bożej Ducha Świętego, ponieważ Hermas mówi o grzechach jako o złych duchach, a o cnotach jako o dobrych duchach. Jednakże dobre duchy pochodzą z Ducha Bożego. „Każdy duch dany od Boga nie czeka na pytania, lecz znając moc Bożą mówi sam z siebie... [bo] przychodzi z mocy Ducha Bożego. Natomiast duch, którego trzeba pytać i który mówiąc dostosowuje się do pragnień ludzkich, jest duchem z ziemi rodem... i nie jest tak, że kiedy człowiek ma ochotę mówić, wtedy mówi Duch Święty, lecz mówi On tylko wtedy, gdy Bóg chce, aby mówił... Czyż Duch Boży może przyjmować zapłatę za proroctwo? ... Duch takich proroków jest rodem z ziemi!" (por. Pasterz 43, 5-21).

W ten sposób Hermas prezentuje swoją teologię Ducha Świętego. Duchy, którym trzeba zadawać pytania, są duchami rodem z ziemi. Duch zaś Boży nie przemawia jak wyrocznia, ale mówi tylko wtedy, gdy Bóg chce, aby mówił. W starożytności chrześcijanie przeciwstawiali się zwyczajowi chodzenia do wyroczni i zadawania jej pytań, na które ona odpowiadała, ujawniając zainteresowanemu wiedzę na temat przyszłości niezależnie od jego życia ${ }^{61}$. Na poparcie myśli Hermasa można przytoczyć słowa z Nowego Testamentu, że „Duch Boży wieje tam, gdzie chce” (por. J 3, 8); „Kto ma uszy, niechaj posłyszy, co mówi Duch do Kościołów” (Ap 2, 7. 11. 17. 29; 3, 6. 13. 22) oraz słowa Pawła apostoła o sumieniu w Duchu Świętym (por. Rz 9, 1-2).

Duch Święty nie odpowiada publicznie ani na publiczne ludzkie pytania. Jego słowa i zapewne także działania nie odpowiadają na oczekiwania ludzi, ale prezentuje On ludziom Boże oczekiwania wobec nich. Dla grzeszników proponuje nawrócenie (metanoia). Grzechów nie da się przezwyciężyć zakazami, nakazami ani karami. Jeśli mówimy, że dopiero Kościół w IV wieku zainteresował się Duchem Świętym, to istotnie teologia się Nim wtedy bardziej zainteresowała, ponieważ wspólnota żyła Duchem od samego początku. Wyrazem tego jest modlitwa chrześcijańska, do której zachęcał Jezus, a każda modlitwa jest rozmową z Bogiem.

${ }^{61}$ O magii i wróżbach w świecie starożytnym por. A. Baron, Magia i czary w Konstytucjach apostolskich, Opole 2013, s. 76-82 (Opolska Biblioteka Teologiczna, 138). 
W aspekcie antropologicznym Hermas stwierdza, że duch zamieszkuje w człowieku (por. Pasterz 59, 7) oraz że skalanie ciała jest skalaniem Ducha Świętego, który w nim mieszka (por. Pasterz 60, 1-2. 4). Należy tu mieć na względzie trychotomię obecną w pismach Nowego Testamentu (duch, dusza, ciało), która przeszła w dychotomię (dusza, ciało) wprawdzie w pełni dopiero w V wieku, ale współczesny czytelnik odczytuje słowa Pasterza w klimacie dychotomicznym i słowa te muszą brzmieć dwuznacznie: mowa w nich o „duchu świętym”, ale duch Boży, którego nam Bóg udziela także jest święty. Wynika stąd, że Bóg obdarza nas swoją świętością, ale jest ona zarówno dana, jak i zadana, to znaczy człowiek swoim życiem decyduje o jej trwałości i ze względu na swoją wolność może ją skalać. Dlatego Pasterz nawołuje do podjęcia wysiłku nawrócenia i trwałej zażyłości z Duchem Świętym.

Nawrócenie jest łaską Boga, który „daje ducha pokuty” (Pasterz 72,1) każdemu, kto gotowy jest Mu służyć, a przebiegłym i zamierzającym pokutować tylko z pozoru odmawia łaski nawrócenia (por. Pasterz 72, 2). W innym miejscu Hermas dziękuje Panu za to, że posłał Anioła Pokuty (por. Pasterz 91, 3), dając możliwość nawrócenia również dla upadłych po chrzcie.

\section{Duch Święty w relacji do Syna Bożego według Pasterza}

Przytoczyliśmy powyżej opinię Simonettiego, że Hermas identyfikuje Ducha Świętego z Synem Bożym. Dotyczy to wypowiedzi z Pasterza 59, 5 oraz 78, 1. Luigi Cirillo, omawiając fragment Pasterza 59, 5 o zamieszkiwaniu Ducha Świętego w Jezusie w szerszym kontekście Pasterza 59, 4-6, w którym Hermas werbalizuje tajemnicę Wcielenia, zauważa, że idzie tu o zamieszkiwanie Ducha Świętego w Słudze Jahwe z Deutero-Izajasza Iz 42, ${ }^{62}$. Szerzej omawia ten temat Szulc ${ }^{63}$.

62 Por. L. Cirillo, La christologie pneumatique de la cinquième parabole du „Pasteur" d'Hermas (Par. V,6,5), „Revue de l'histoire des religions” 184 (1973), s. 25-48.

63 Por. F. Szulc, Syn Boży w „Pasterzu” Hermasa, dz. cyt., s. 117-151. 
Podstawowym pytaniem pozostaje, mimo wielu wspomnianych studiów na ten temat, czy Hermas rzeczywiście utożsamia Osobę Ducha Świętego z Osobą Syna Bożego? W Pasterzu czytamy: „Syn jest Duchem Świętym, a niewolnik Synem Bożym” (58, 2); „Duchowi Świętemu, który jest od wieków... zgotował Bóg mieszkanie w ciele” $(59,5)$ oraz „Anioł Pokuty przyszedł i powiedział: Chcę ukazać ci wszystko, co ci ukazał Duch Święty, który przemawiał do ciebie pod postacią Kościoła. Duch ten bowiem jest Synem Bożym" $(78,1)$.

W opinii niektórych badaczy Duch Święty według Hermasa wcielił się w Jezusa. W ten sposób Hermas ich zdaniem utożsamia Ducha Świętego i Syna Bożego. Czy pogląd taki pokazuje niezrozumienie przez Hermasa prawd chrystologicznych i trynitarnych? Zanim udzieli się odpowiedzi, należy sobie uświadomić, że w II wieku brakuje jasnych rozstrzygnięć dotyczących Osoby Ducha Świętego. Kościół zdefiniował je po latach sporów i dyskusji dopiero na soborach w IV i V wieku. Problem w tym, że odpowiedź na interesujące nas pytanie zależy od tego, co oznaczają dla Hermasa w przytoczonych fragmentach słowa „duch święty” oraz „syn Boży”: Ducha Świętego czy Boską naturę Jezusa? Sprawę przebadał Franciszek Szulc i doszedł do stwierdzenia, że określenia Hermasa „nadal pozostają niedookreślone, a nawet wieloznaczne" i nieco dalej dodaje: „termin Syn nie jest tożsamy znaczeniowo z terminem «Syn Boży». W innym znaczeniu Duch Święty jest Synem Boga, a w innym znaczeniu orzeka się o Słudze, że jest Synem Bożym. Pomieszanie lub nierozróżnianie tych znaczeń prowadzi do zarzutu utożsamienia Ducha Świętego i Syna Bożego. W historii interpretacji Pasterza mamy wiele przykładów błędnego odczytywania pierwotnych znaczeń występujących w tekście. Do najstarszych i najczęstszych należy utożsamianie Ducha Świętego z Synem Bożym"64. Na kilku następnych stronach Szulc szeroko argumentuje przytoczone tu jego stanowisko w tej kwestii. Identyfikowanie Ducha Bożego z Chrystusem nie występuje wyłącznie u Hermasa, ale natrafiamy na nie u Justyna Rzymskiego (Apologia I, 33, 6) i u Ireneusza (Adverus haereses III, 10,3), u którego jednak oznacza naturę Bożą Chrystusa, a niekoniecznie Osobę Ducha Świętego.

${ }^{64}$ Por. F. Szulc, Syn Boży w „Pasterzu” Hermasa, dz. cyt., s. 144-146. 


\section{Zakończenie}

Pogański świat w starożytności był pełen demonów, odznaczał się sporym wyczuciem w sprawach duchowych, podkreślając prymat ducha, zwłaszcza w platonizmie. Wraz z chrześcijaństwem wyrosłym z judaizmu pojawiło się w świecie greckim zupełnie nowe ujęcie świata duchowego, który reprezentowali aniołowie, duchy święte i duchy złe, czyli demony. Te dwa duchy (czy rodzaje duchów) wyrażały możliwość podwójnego wewnętrznego ukierunkowania człowieka, które dzisiaj określamy skłonnością do dobra i skłonnością do zła. Najważniejszym novum była jednak w tym względzie Osoba Ducha Świętego.

W pierwszych dwóch wiekach chrześcijaństwa nawet ogólne pojęcie ducha nie było precyzyjnie określane. Nic dziwnego, że w odniesieniu do Boga, który jest duchem świętym, którego Syn jest duchem świętym, i od którego pochodzi Duch Święty, także będący duchem świętym, nawet nie podejmowano próby szczegółowej werbalizacji Jego tajemnicy. Teksty zapisane z uwzględnieniem rozróżnienia na małe i duże litery pewnie wydają się dla nas w pełni zrozumiałe, przynajmniej znaczeniowo, ale starożytni nie stosowali takiego rozróżnienia, chociaż potrafili bardzo precyzyjnie wyrażać swoje myśli. Pobieżna lektura ich pism może prowadzić do nieporozumień, zwłaszcza że docierają one do nas w formie interpretacji współczesnych wydawców, narzucających ich myślom rzekomo autentyczną i precyzyjną pisownię. Czy jednak wyraża to bardziej rzeczywistość Ducha Świętego? W świetle słów Pawła Apostoła: „Kto poznał myśl Pana, albo kto był jego doradcą?" (Rz 11, 34), raczej nie. Dlatego jakkolwiek Kościół pierwotny posiadał bogate znaczeniowo terminy odnoszące się do świata duchowego, to prawdy wiary dotyczące Osoby Ducha Świętego starano się precyzyjnie werbalizować tylko w przypadku ich negacji przez heretyków, zwłaszcza w IV wieku.

W odniesieniu do Pasterza Hermasa trzeba uwrażliwić przed pochopnym wyciąganiem wniosków dotyczących Ducha Świętego bez uwzględnienia złożonej jego struktury i związków ze światem hebrajskim, greckim i rzymskim. Jedynie dogłębna znajomość wskazanych tu aspektów starożytności, zwłaszcza myśli judeochrześcijańskiej, może pomóc w uniknięciu błędów wielu badaczy, którzy się zajmowali tym dziełkiem. 
Nie trzeba tłumaczyć, jakie konsekwencje pociągają za sobą błędne interpretacje, zwłaszcza posądzające kogoś o poglądy nieortodoksyjne.

Pasterz Hermasa ukazuje delikatność Ducha Świętego, który pozostawia człowiekowi wolność i nie narzuca się ze swoją Boską mocą, ale ustępuje w przypadkach, gdy człowiek podejmuje sposób życia niezgodny z wolą Bożą, zawsze pozostając do dyspozycji oczekujących Jego obecności. Tylko On, Duch Święty, jest źródłem zjednoczenia człowieka z Bogiem. Tylko On umożliwia powrót człowieka do Boga, nawet jeśli człowiek popełni grzech już po przyjęciu chrztu. Tylko On umożliwia i warunkuje autentyczne nawrócenie, określane w Pasterzu greckim słowem metanoia. Uderza realizm obecności Ducha Świętego w człowieku ochrzczonym, nawet jeśli popełni kolejne grzechy. Zapewne chodzi o inny sposób Jego obecności, ale jakakolwiek by ona była - świadczy o wierności Boga i zarazem o współodpowiedzialności chrześcijanina za Ducha, którego nosi w sobie. Niewątpliwie wizja Ducha Świętego w Pasterzu jest prosta, ale w pełni oddaje Jego zbawcze działanie uświęcające, które umożliwia człowiekowi szczęście wieczne i uniknięcie kary, nie na drodze przymusu i narzucania swej woli, ale szczerego żalu i nawrócenia.

W wieku XX pojawiły się ruchy pentekostalne, grupy charyzmatyczne i odnowy w Duchu Świętym, które zaowocowały ożywieniem chrześcijaństwa na wszystkich kontynentach, ale równocześnie uwidoczniły duże różnice w pojmowaniu rzeczywistości duchowych. Pomimo dwóch tysięcy lat chrześcijaństwa poglądy o Osobie Bożej Ducha Świętego nadal nie docierają do wielu ludzi w formie integralnej a zarazem przystępnej. Może warto skorzystać z szerokich znaczeniowo pojęć, na które natrafiamy w Pasterzu Hermasa oraz ze sposobu ich stosowania, aby pobudzać i dziś ludzi do wsłuchiwania się w głos Duch Świętego, który nadal działa i poucza (por. J 16, 13), wzywając do nawrócenia także chrześcijan. Tym jednym słowem „nawrócenie” (metanoia) można streścić orędzie Ducha w małym pod względem rozmiarów dziełku Hermasa pt. Pasterz, które czytano w Rzymie jako natchnione, które stanowiło próbę werbalizacji prawdy o Bogu i o Jego miłości do człowieka grzesznego. Podkreślmy, próbę werbalizacji, bo Prawdą i Miłością jest On sam. 


\section{Summary}

\section{Nauka o Duchu Świętym w „Pasterzu” Hermasa na tle problematyki pneumatologicznej. Studium wprowadzające}

Celem artykułu jest pokazanie złożoności problematyki dotyczącej świata duchowego i świata duchów, z którą zmierzały się poczynając od czasów starożytnych kolejne pokolenia ludzi ztrzech różnych cywilizacjii kultur,od semickiej przezhelleńską aż do łacińskiej. Dotyczy to także pojmowania Ducha Świętego, zwłaszcza w dwóch pierwszych wiekach. Na takim tle zostaną przedstawione uwagi na temat poglądów Pasterza Hermasa, którego pneumatologia jakkolwiek prosta, łączy wspomniane trzy światy, ponieważ autor dziełka wywodzi się z judaizmu, spisał swoje myśli po grecku i dokonał tego w Rzymie. Pasterz jest kapitalnym świadectwem chrześcijan pierwszych wieków w ukazywaniu działania Ducha Świętego, który będąc Bogiem okazuje swoją wielką delikatność wobec człowieka grzesznego, umożliwia mu powrót do Boga, ale w każdej chwili respektuje dokonywane przez niego wolne wybory.

Słowa kluczowe: Pasterz Hermasa, Duch Święty, pneumatologia patrystyczna

\section{A Study of the Holy Spirit in the Shepherd of Hermas in the Context of Pneumatological Problems (Introduction)}

The goal of this article is to show the complexity of the spiritual world and the world of spirits and how ancient generations of people from three different civilizations and cultures, Semitic, Hellenistic and Latin, dealt with it. This also applies to the understanding of the Holy Spirit, especially in the first two centuries. From this background, comments are made about the views of the Shepherd of Hermas, whose pneumatology, however simple, combines the three worlds, because the author of the work came from Judaism, wrote his thoughts in Greek and did it in Rome. The Shepherd is a great testimony of Christians in the first centuries, showing how the Holy Spirit who, being God, shows his great gentleness towards sinful man and enables him to return to God, but at the same time respects his free choices.

Keywords: The Shepherd of Hermas, Holy Spirit, patristic pnematology

\section{Bibliografia}

Baron A., Mariusz Wiktoryn - człowiek i jego dzieło. Wprowadzenie do dziet egzegetycznych, Kraków 1999, s. 5-65 (ŹMT, 13).

Baron A., Neoplatonizm a chrześcijaństwo w pierwszych wiekach, w: Wczesne chrześcijaństwo a religie, red. I. Ledwoń, M. Szram, Lublin 2012, s. 425-454. 
Baron A., Świętość a ideały człowieka (Ojcowie Apostolscy, Klemens Aleksandryjski, Orygenes). Studium teologiczne na tle modeli filozoficzno-religijnych, Kraków 2013.

Baron A., Magia i czary w Konstytucjach apostolskich, Opole 2013, s. 75-95 (Opolska Biblioteka Teologiczna, 138).

Baron A., Głoszenie Chrystusa i jego recepcja w starożytności i dziś w aspekcie przepowiadanej treści, w: Głoszenie Pana Jezusa Chrystusa. Treść przepowiadania, red. H. Sławiński, Kraków 2017, s. 87-118 (Ancilla Verbi, 4).

Canobbio G., http://www.teologiamilano.it/teologiamilano/ allegati/614/08_ pneumatologia.pdf (18.03.2019).

Cirillo L., La christologie pneumatique de la cinquième parabole du „Pasteur" d'Hermas (Par. V, 6, 5), ,Revue de l'histoire des religions” 184 (1973), s. 25-48.

Congar Y., Credo nello Spirito Santo, Brescia 1998.

Częsz B., Związek Ducha Świętego z Kościołem w ujęciu świętego Ireneusza i w interpretacji montanistycznej, Poznań 1991.

Częsz B., Duch Święty został nam dany. Nauczanie Ojców i wiara starożytnego Kościoła, Gniezno 1998.

Daniélou J., Teologia judeochrześcijańska, tłum. S. Basista, Kraków 2002.

Epifaniusz z Salaminy, Panarion: herezje 1-33, tłum. M. Gilski, Kraków 2015. 70).

Euzebiusz z Cezarei, Historia kościelna, tłum. A. Caba, A. Lisiecki, Kraków 2013 (ŹMT,

Fredrikson N. I., L'Esprit Saint et les esprits mauvais dans le Pasteur d'Hermas: Sources et prolongements, „Vigiliae Christianae” 55 (2001), s. 262-280.

Haas C., Die Pneumatologie des "Hirten des Hermas”, w: Aufstieg und Niedergang der Römischen Welt, Hrsg. W. Haase, Teil 2, Bd. 27/1, Berlin-New-York 1993, s. 552-586.

Hauschild W.-D, Drecoll V. H., Pneumatogie in der Alten Kirche, Bern 2004.

Hipolit, Przeciw Noetosowi, tłum. S. Kalinkowski, Kraków 1997, s. 87-101 (ŹMT, 4).

Kołosowski T., Nauka Ojców Kościoła o Duchu Świętym. Wybrane zagadnienia, „Seminare" 13 (1997), s. 249-267.

Lambiasi F., Vitali D., Spirito Santo. Mistero e presenza. Per una sintesi di pneumatologia, Bologna 2005.

La vita nello Spirito, a cura di G. Canobbio, F. Dalla Vecchia, R. Tononi, Brescia 2012 (Quaderni Teologici del Seminario di Brescia, 22).

Lo Spirito Santo nella testimonianza dei Padri e degli Scrittori cristiani., Secoli I-V, ed. G. Di Nola, Roma 1999.

Lo Spirito. Percorsi nella filosofia e nelle culture, a cura di M. Pagano, Milano-Udine 2011.

Maier J., Między Starym a Nowym Testamentem, tłum. E. Marszał, J. Zakrzewski, Kraków 2002.

Martin J.P., Espíritu y dualismo en el Pastor de Hermas y su relación con el judaísmo, „Vetera Christianorum” 15 (1978), s. 295-345.

Moltmann J., Lo Spirito della vita. Per una pneumatologia integrale, Brescia 1994.

Naumowicz J., Wstęp, w: Św. Bazyli Wielki, O Duchu Świętym, tłum. Alina Brzóstkowska, Warszawa 1999, s. 5-77. 
Orygenes, O zasadach, tłum. S. Kalinkowski, Kraków 1996 (ŹMT, 1).

Pietras H., Początki teologii Ducha Świętego, w: Św. Atanazy Wielki, Listy do Serapiona, Kraków 1996, s. 5-67 (ŹMT, 2).

Pietras H., Początki teologii Kościoła, Kraków 2007.

Putney M. E., Come, Holy Spirit, renew the whole Creation: seventh assembly of the World Council of Churches, „Theological Studies” 52 (1991), s. 607-635.

Simonetti M., Note di cristologia pneumatica, „Augustinianum” 12 (1972) n. 2, s. 201-232.

Simonetti M., La crisi ariana nel IV secolo, Roma 1975.

Słomka J., Nowe proroctwo. Historia i doktryna montanizmu, Katowice 2007.

Spirito Santo, w: Dicionario patristico e di antichità cristiane, vol. 2, a cura A. Di Bernardino, Casale Monferrato 1983-1988, kol. 3296-3298.

Staniek E., Angelologia w „Pasterzu” Hermasa, „Studia Theologica Varsoviensia” 9 (1971) nr 1, s. 51-82.

Swete H. B., The Holy Spirit in the Ancient Church, London 1912.

Szulc F., Syn Boży w „Pasterzu” Hermasa. Świadectwo chrystologii judeochrześcijańskiej, Katowice 2006 (Studia Antiquitatis Christianae, Series Nova, 2).

Tertulian, Przeciw Prakseaszowi, tłum. E. Buszewicz, Kraków 1997, s. 33-86 (ŹMT, 4).

Triacca A. M., Lo Spirito Santo nella liturgia e nella vita della Chiesa, Città del Vaticano 2011.

Verso una nuova età dello Spirito. Filosofia, teologia, movimenti, a cura di G. Colzani, Padova 1997 (Studi religiosi).

Welker W., Gottes Geist. Theologie des Heiligen Geistes, Neukirchen-Vluyn 1993. 